\title{
Effect of airborne particle abrasion protocols on surface topography of Y-TZP ceramic
}

\section{(Efeito do protocolo de jateamento com partículas na topografia da superfície de uma cerâmica Y-TZP)}

\author{
J. R. C. Queiroz ${ }^{1}$, G. P. Paulo ${ }^{1}$ M. Özcan ${ }^{2}$ L. Nogueira Jr. ${ }^{1}$ \\ ${ }^{1}$ Department of Dental Materials and Prosthodontics, S. Jose dos Campos Dental School, S. Paulo State \\ University - UNESP, R. Eng. Francisco José Longo 777, \\ Jardim S. Dimas, S. José dos Campos, SP 12245-000, Brazil \\ ${ }^{2}$ Dental Materials Unit, Center for Dental and Oral Medicine, Clinic for Fixed and Removable Prosthodontics \\ and Dental Materials Science, University of Zürich, Plattenstrasse 11, CH-8032, Zürich, Switzerland \\ joserenatocq@hotmail.com
}

\begin{abstract}
This study aimed to evaluate Y-TZP surface after different airborne particle abrasion protocols. Seventy-six Y-TZP ceramic blocks $(5 \times 4 \times 4) \mathrm{mm}^{3}$ were sintered and polished. Specimens were randomly divided into 19 groups $(\mathrm{n}=4)$ according to control group and 3 factors: a) protocol duration ( 2 and $4 \mathrm{~s})$; b) particle size $(30 \mu \mathrm{m}$, alumina coated silica particle; $45 \mu \mathrm{m}$, alumina particle; and $145 \mu \mathrm{m}$, alumina particle) and; c) pressure (1.5, 2.5 and 4.5 bar). Airborne particle abrasion was performed following a strict protocol. For qualitative and quantitative results, topography surfaces were analyzed in a digital optical profilometer (Interference Microscopic), using different roughness parameters (Ra, Rq, Rz, X-crossing, Mr1, Mr2 and Sdr) and 3D images. Surface roughness also was analyzed following the primer and silane applications on Y-TZP surfaces. One-way ANOVA revealed that treatments (application period, particle size and pressure of particle blasting) provided significant difference for all roughness parameters. The Tukey test determined that the significant differences between groups were different among roughness parameters. In qualitative analysis, the bonding agent application reduced roughness, filing the valleys in the surface. The protocols performed in this study verified that application period, particle size and pressure influenced the topographic pattern and amplitude of roughness.
\end{abstract}

Keywords: zirconia, surface modification, sandblast.

Resumo

O objetivo deste estudo foi avaliar a superfície de uma cerâmica à base de zircônia tetragonal estabilizada por ítria (Y-TZP) após diferentes protocolos de jateamento com partículas. Setenta e seis blocos cerâmicos de Y-TZP (5 $x 4 \times 4) \mathrm{mm}^{3}$ foram sinterizados e polidos. As amostras foram randomicamente divididas em 19 grupos $(n=4)$ sendo um controle e 18 grupos utilizando 3 fatores: a) tempo (2 e $4 \mathrm{~s}$ ); b) tamanho de partícula (30 $\mu \mathrm{m}$ - partículas de alumina revestida por sílica; $45 \mu \mathrm{m}$ - partículas de alumina; $145 \mu \mathrm{m}$ - partículas de alumina) e; c) pressão $(1,5,2,5$ e 4,5 bar). O jateamento foi realizado seguindo um rigoroso protocolo. Para os resultados qualitativos e quantitativos a topografia da superfície foi analisada em um perfilometro óptico digital (microscopia de interferência), utilizando diferentes parâmetros de rugosidade (Ra, Rq, Rz, $X$-crossing, Mrl, Mr2 e Sdr) e imagens 3D. A rugosidade da superfície também foi analisada após a aplicação de agentes de união (primer e silano) sobre a superficie cerâmica. ANOVA 1-fator revelou que os tratamentos de superfície (tempo, tamanho de partícula e pressão durante o jateamento) forneceram resultados com diferença estatisticamente significante para todos os parâmetros de rugosidade analisados. O teste de Tukey mostrou que as diferenças estatísticas entre os grupos foram diferentes para cada parâmetro. Na análise qualitativa os agentes de união reduziram a rugosidade, preenchendo os vales da superfície. Os protocolos realizados neste estudo mostram que o tempo, o tamanho da partícula e a pressão influenciaram no padrão topográfico e na amplitude da rugosidade da cerâmica $Y$-TZP.

Palavras-chave: zirconia, modificaçao da superfície, jateamento.

\section{INTRODUCTION}

Y-TZP bonding has been a topic of great interest in recent years [1-8] for further expansion dependable applications of this esthetic restorative material [9]. For clinical purposes, the traditional bonding protocol used in other ceramic systems is ineffective on zirconia surfaces $[6,10]$. Microstructural and compositional optical profilometry analysis revealed an acid resistant ceramic, since hydrofluoric acid (HF) treatment produced a pattern with insufficient roughness for resin bonding $[5,11]$. Thus, the optimal surface conditioning method to achieve zirconia reliable bond strength must be 
investigated. However, surface changes seem to be necessary to achieve a stable bond with resin cements $[6,12]$.

New chemical adhesives and different surface treatment techniques have been investigated to enhance the bond strength of luting cements to zirconia-based ceramic surfaces [7, 9, 13-17]. Numerous studies have treated the Y-TZP surface with the airborne particle abrasion systems $[6,8,9,12-14,17-32]$, even so, no consensus exists in the dental literature that the air abrasion method is efficient in improving adhesion of the luting agents to Y-TZP ceramics [27]. Two types of abrasives particles have been applied: alumina particles (sandblasted, SB) and silica modified alumina particles (silica coating systems, SC) using differing the particles sizes $[6,33]$. These mechanical surface modifications should improve the resin-ceramic bonding by: a) removing any organic contaminants from the ceramic surface; b) improving the wetting kinetics of adhesives; c) increasing the bonding surface; d) increasing surface roughness $[8,12]$, promoting micromechanical interlocking resin $[5,25]$, since the original roughness produced by milling during fabrication is not sufficient to promote adhesion [19]; and e) depositing a silica layer on the Y-TZP surface, enabling the silane reactions that occur in the SC method $[6,28]$. Thus air abrasion by alumina and alumina-coated silica particles plays an important role in improving the bond strength of resin cements to oxide ceramics $[5,6,25,28]$.

The surface treatment protocol using air abrasion methods can consist of: a) previous sample polishing; b) the type of particle used for air abrasion; c) particle size and; d) the blasting pressure, angle, duration and distance. Different Y-TZP and posterior cleaning methods applied after polishing samples can influence bonding test results [33].

Using the PubMed electronic database (limited to dental journals) and entering the key words "zirconia" and "bonding", for articles published from 2006 onward, revealed 49 different protocols for airborne particle abrasion on zirconia surface $[1-10,12-14,17-19,22-$ 32, 34-42]. These studies reported different polishing techniques on initial samples, a large range of particle sizes $(30,50$ and $100 \mu \mathrm{m}$ for SC, and 25, 50, 70, 90, 110 and $125 \mu \mathrm{m}$ for $\mathrm{SB})$ and varying pressure range (0.5 at 7 bar) and protocol duration (5 to $20 \mathrm{~s}$ ). Two distances between the microjet and sample were used ( 5 and 10 $\mathrm{mm})$. The most common particle sizes used were: $30 \mu \mathrm{m}$, alumina coated silica particle (6 works using 13 different protocols) $[21,23,25,26,28,31]$ and $50 \mu \mathrm{m}$, alumina particle (16 works using 19 different protocols) $[6,8,9$, $12,17-20,24,25,27-29,32,37,42]$. The most common pressure (a) and duration (b) used were: a) 2.5 bar (8 times) and 2.8 bar (13 times) and; b) $10 \mathrm{~s}$ (in 19 protocols) and $13 \mathrm{~s}$ (in 10 protocols). The distance of $10 \mathrm{~mm}$ was reported in 37 different protocols.

The conflicting results verified in the literature regarding bond strength using SB and SC methods may be attributed to the fact that different investigators did not use the same protocol and brands of zirconia materials. While all zirconia-based ceramics are similar from a chemical standpoint, structural differences may exist $[9,33]$. In this brief review, 10 different Y-TZP ceramics were identified in the studies. Procera, Lava and Cercon ceramics were the most commonly used brands. Different cleaning solutions used following air abrasion also were identified (ethanol, isopropanol, distilled water, acetone). These results demonstrate the variety of protocols in studies that investigated the bond strength of luting agent for Y-TZP ceramics. Different surface treatment can produce different retentive patterns on ceramics with different microstructure [5]. Therefore, it may not be reasonable to generalize conclusions drawn from a specific protocol.

The methods used to change ceramic surface topography and increase bond strength have not been precisely quantified and the influence of airborne particle abrasion on zirconia ceramics is still largely unknown [13, 30]. The aim of this study was to evaluate the effect of different air abrasion protocols on the surface roughness of Y-TZP ceramic. The null hypothesis is that different protocols have distinct influences on surface roughness pattern.

\section{MATERIALS AND METHODS}

\section{Production of specimens}

The brand names, material types, main compositions, manufacturers and batch numbers of the products used in the current study are presented in Table I.

Seventy-six Y-TZP ceramic (Cercon Zirconia, Dentsply Ceramco, York, USA) blocks $(5 \times 4 \times 4) \mathrm{mm}^{3}$ were sintered and polished with silicon carbide emery paper (1200 grit) under water cooling. All specimens were submitted to sonic bath (Vitasonic, Vita Zanhfabrik, Germany) for $10 \mathrm{~min}$ in distilled water. The specimens were embedded in chemically activated acrylic resin and were randomly divided into 19 groups $(n=4)$ according to control group (surface polished with no blasting) and 3 factors for roughness analysis by Interference Microscopy: a) protocol duration ( 2 and $4 \mathrm{~s})$; b) particle size $(30 \mu \mathrm{m}$, alumina coated silica particle; $45 \mu \mathrm{m}$, alumina particle; and $145 \mu \mathrm{m}$, alumina particle) and; c) pressure $(1.5,2.5$ and 4.5 bar) (Table II).

Air abrasion was applied in the same place without any movement of a specific blasting device (Cojet-PrepTM, $3 \mathrm{M}$ ESPE AG). The distance between the ceramic surface and the device was standardized at $10 \mathrm{~mm}$ and an inclination of $90^{\circ}$.

\section{Topography analysis}

For qualitative and quantitative topographic analysis and roughness of the ceramic following surface treatment, the samples were evaluated in a Wyko digital optical profilometer (NT 1100, Veeco, USA) that was connected to 
Table I - Brand name, composition, manufacturer and batch number of materials used in the current study. [Tabela I - Nome comercial, composição, fabricante e número de série dos materiais usados na pesquisa.]

\begin{tabular}{|c|c|c|c|}
\hline Brand Name & Main Composition & Manufacture & Batch Number \\
\hline Cercon Zirconia & $\begin{array}{l}\text { Zirconium oxide, yttrium oxide, } \\
\text { hafnium oxide }\end{array}$ & Dentsply Ceramco, York USA & $318900-3$ \\
\hline Monobond-S & Ethanol, water, silane, acetic acid & Ivoclar Vivadent, Schaan, Leichtenstein & N01595 \\
\hline $\begin{array}{l}\text { Metal/Zirconia } \\
\text { Primer }\end{array}$ & $\begin{array}{c}\text { Alcohol, Methyl isobutyl ketone, } \\
\text { Phosphonic acid acrylate, } \\
\text { Benzoylperoxide }\end{array}$ & Ivoclar Vivadent, Schaan, Leichtenstein & M68692 \\
\hline $\begin{array}{l}\text { Óxido de alumínio, } \\
\qquad 45 \mu \mathrm{m}\end{array}$ & Aluminum oxide & Polidental Wilson, Cotia, Brazil & 20919 \\
\hline $\begin{array}{l}\text { Óxido de alumínio, } \\
\qquad 145 \mu \mathrm{m}\end{array}$ & Aluminum oxide & Polidental Wilson, Cotia, Brazil & 21567 \\
\hline Cojet, $30 \mu \mathrm{m}$ & $\begin{array}{l}\text { Aluminum oxide with silicon } \\
\text { oxide coating }\end{array}$ & 3M ESPE, St Paul, USA & 403030 \\
\hline
\end{tabular}

Table II - Experimental groups according to the "particle", "duration" (s) and "pressure" (bar) used in sandblasting. [Tabela II - Grupos experimentais de acordo com a "partícula”, "duração" (s) e "pressão" (bar) usadas no jateamento.]

\begin{tabular}{cccc}
\hline Groups & $\begin{array}{c}\text { Particle Size } \\
(\mu \mathrm{m})\end{array}$ & $\begin{array}{c}\text { Duration } \\
(\mathrm{s})\end{array}$ & $\begin{array}{c}\text { Pressure } \\
(\text { bar })\end{array}$ \\
\hline $\mathrm{A}$ & - & - & - \\
$\mathrm{B}$ & $\mathrm{Al}_{2} \mathrm{O}_{3}-45$ & 2 & 1.5 \\
$\mathrm{C}$ & $\mathrm{Al}_{2} \mathrm{O}_{3}-45$ & 2 & 2.5 \\
$\mathrm{D}$ & $\mathrm{Al}_{2} \mathrm{O}_{3}-45$ & 2 & 4.5 \\
$\mathrm{E}$ & $\mathrm{Al}_{2} \mathrm{O}_{3}-145$ & 2 & 1.5 \\
$\mathrm{~F}$ & $\mathrm{Al}_{2} \mathrm{O}_{3}-145$ & 2 & 2.5 \\
$\mathrm{G}$ & $\mathrm{Al}_{2} \mathrm{O}_{3}-145$ & 2 & 4.5 \\
$\mathrm{H}$ & $\mathrm{Cojet}-30$ & 2 & 1.5 \\
$\mathrm{I}$ & $\mathrm{Cojet}_{2}-30$ & 2 & 2.5 \\
$\mathrm{~J}$ & $\mathrm{Cojet}^{2} 30$ & 2 & 4.5 \\
$\mathrm{~K}$ & $\mathrm{Al}_{2} \mathrm{O}_{3}-45$ & 4 & 1.5 \\
$\mathrm{~L}$ & $\mathrm{Al}_{2} \mathrm{O}_{3}-45$ & 4 & 2.5 \\
$\mathrm{M}$ & $\mathrm{Al}_{2} \mathrm{O}_{3}-45$ & 4 & 4.5 \\
$\mathrm{~N}$ & $\mathrm{Al}_{2} \mathrm{O}_{3}-145$ & 4 & 1.5 \\
$\mathrm{O}$ & $\mathrm{Al}_{2} \mathrm{O}_{3}-145$ & 4 & 2.5 \\
$\mathrm{P}$ & $\mathrm{Al}_{2} \mathrm{O}_{3}-145$ & 4 & 4.5 \\
$\mathrm{Q}$ & $\mathrm{Cojet}_{-30}$ & 4 & 1.5 \\
$\mathrm{R}$ & $\mathrm{Cojet}_{-30}$ & 4 & 2.5 \\
$\mathrm{~S}$ & $\mathrm{Cojet}-30$ & 4 & 4.5 \\
\hline
\end{tabular}

a computer drive containing the software Vision 32 (Veeco, USA). The roughness measurement parameters were performed at a magnification of $20 \times$ on two representative areas of each sample $(301.3 \times 229.2) \mu \mathrm{m}$ in the centre of the blasted area. The roughness parameters evaluated were: 1. Amplitude parameters (bidimensional); i.e., description of height: a) Ra, arithmetical mean of the absolute values of the surface departures from the mean plane within the sampling area. The parameter was measured in $\mu \mathrm{m}$, which is a general and commonly used parameter; b) Rq, the root mean square value of the surface departures within the sampling area (measured in $\mu \mathrm{m}$ ). This parameter is more sensitive to extreme values than the Ra parameter due to the squaring operation; c) Rz, the average value $(\mu \mathrm{m})$ of the absolute heights of the five highest peaks and the absolute value of the five deepest valleys within the sampling area. This parameter is sensitive to the changes of pronounced topography features. d) X-Crossing, number of times that the surface crosses the mean plane within sampling area on the X-axis. 2. Functional parameters (tridimensional); i.e., a specific description of surface characteristics: a) Mr1 (peak material ratio), material ratio at the top of the roughness core, which is an estimate of the small peaks above the main flat part of surface. b) Mr2 (valley material ratio), material ratio at the bottom of the roughness core, which is an estimate of the portion of the surface that will carry the load during the life span of the part. c) Sdr (surfaces area ratio), expresses the increment of the interfacial surface area related to the area of the projected (flat) xy plane. For a totally flat surface, the surface area and the area of the xy plane are the same and $\mathrm{Sdr}=0 \%$.

\section{Qualitative analysis}

3D images also were analyzed following the primer (to alumina particles) and silane (to alumina coated silica particles) applications on Y-TZP surfaces after SB and SC, to evaluate the effect of bonding agent application on a rough surface. 


\section{Statistical analysis}

Statistical analysis of the results of all parameters was performed using One-way ANOVA and pos hoc multiple comparisons between groups by the Tukey test. $P$ values $<$ 0.05 were considered statistically significant.

\section{RESULTS}

It was not possible to achieve sandblast with $145 \mu \mathrm{m}$ alumina particle at 1.5 bar. Due to these results, the Groups $\mathrm{E}$ and $\mathrm{N}$ were not considered in the statistical analysis.

One-way ANOVA (Table III) revealed that treatments showed significant difference for all roughness parameters.

Table III - Results of One-way analysis of variance for roughness parameters data $(p<0.05)$.

[Tabela III - Resultado da análise de variância de 1-fator para os dados de diferentes parâmetros de rugosidade $(p<0,05)$.

\begin{tabular}{cccccccc}
\hline & $\mathrm{Ra}$ & $\mathrm{Rq}$ & $\mathrm{Rz}$ & $\begin{array}{c}\mathrm{X}- \\
\text { crossing }\end{array}$ & $\mathrm{Mr} 1$ & $\mathrm{Mr} 2$ & $\mathrm{Sdr}$ \\
\hline$p$ value & 0.0 & 0.0 & 0.0 & 0.0 & 0.0 & 0.0 & 0.0 \\
\hline
\end{tabular}

Descriptive analysis (means and SD) of 2D and 3D parameters (Table IV) suggests that the interaction of different types of particle, duration and variable pressure promoted different topographic patterns on the Y-TZP ceramic surface (Fig. 1).

Analysis by the Tukey test (Table IV) determined significant difference between the groups, indicating that surface treatments promoted different surface roughness for all parameters: $\mathrm{Ra}, \mathrm{Rq}$ and $\mathrm{Rz}$ : larger particles, longer protocol duration and higher pressure all resulted in increased roughness. However, the Tukey test determined differences among mean comparison distribution.

$\mathrm{X}$-Crossing: the alumina coated silica groups presented higher values than the alumina particles groups. Shorter protocol durations and lower pressure increased this parameter.

Mr1: the groups that used a silica coating system (Cojet) showed a higher proportional peak volume than the groups sandblasted with alumina particles. Lower pressure also resulted in higher values. The duration of the protocol had no effect on this parameter. $\mathrm{Mr} 2$ : this parameter showed that the $145 \mu \mathrm{m}$ alumina particles have a higher proportional volume in the valleys than the $45 \mu \mathrm{m}$ alumina particles and the $30 \mu \mathrm{m}$ alumina coated silica particles. With a protocol duration of $4 \mathrm{~s}$ (time factor) the percentage valley volume also increased. Sdr: higher pressure and a longer protocol duration produced a larger surface area. At $2 \mathrm{~s}$, the 30 $\mu \mathrm{m}$ alumina coated silica particle group presented greater proportionality in increasing the surface area than the $45 \mu \mathrm{m}$ alumina particle group and lower than the $145 \mu \mathrm{m}$ alumina particle group.

In qualitative analysis, the bonding agent application reduced roughness, filling the valleys on the surface (Fig. 2).
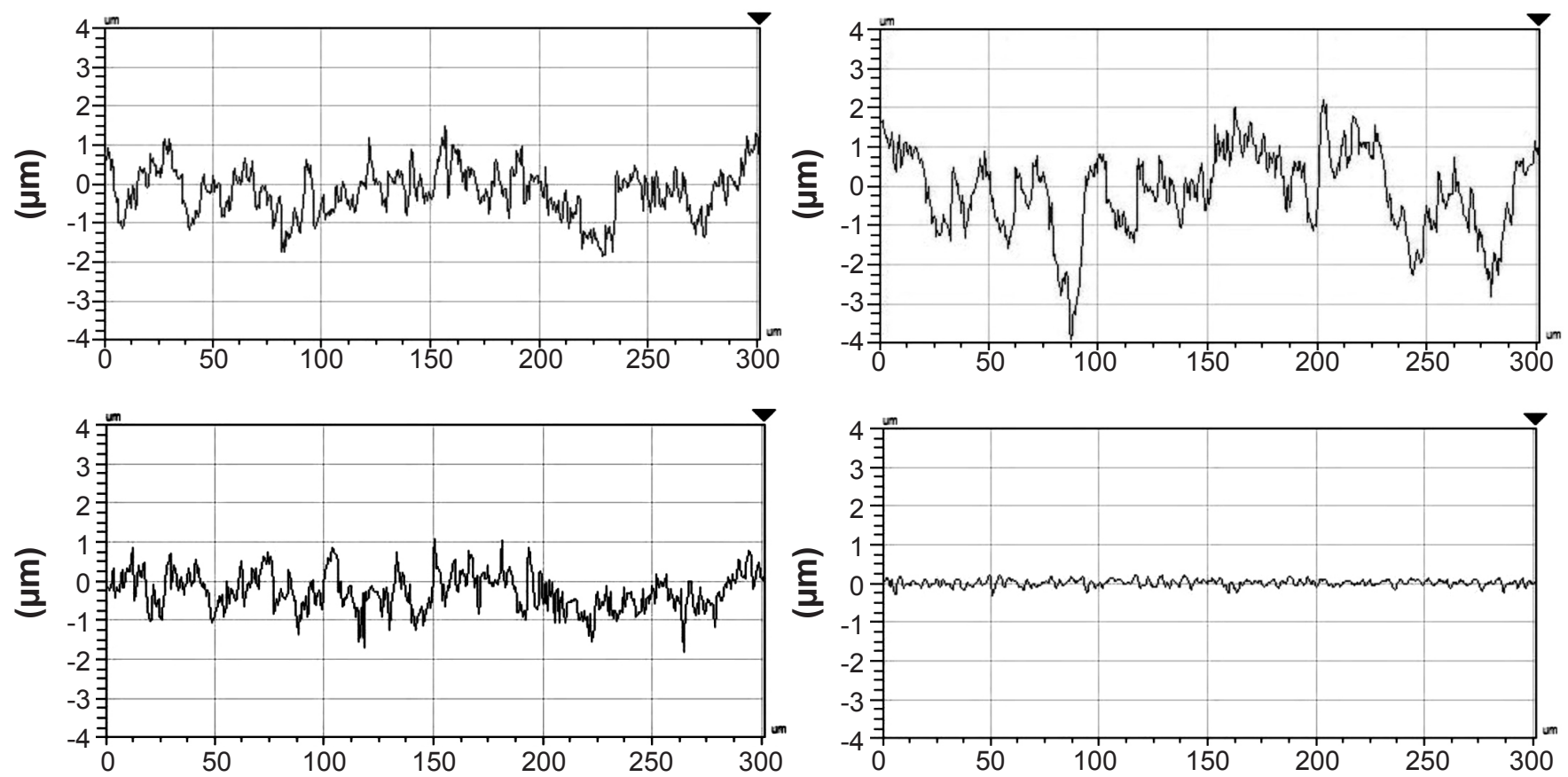

Figure 1: Roughness images and X profiles of Y-TZP surface of: a- group M (alumina particle of $45 \mu \mathrm{m}$ for $4 \mathrm{~s}$ at 4.5 bar); b- group P (alumina particle of $145 \mu \mathrm{m}$ for $4 \mathrm{~s}$ at $4.5 \mathrm{bar}$ ); and c- group S (cojet particle of $30 \mu \mathrm{m}$ for $4 \mathrm{~s}$ at $4.5 \mathrm{bar}$ ).

[Figura 1: Imagens da rugosidade de superficie da cerâmica Y-TZP e gráfico do perfil no eixo X de amostras dos grupos: a- grupo M (partículas de alumina com $45 \mu \mathrm{m}$ por $4 \mathrm{~s}$ a 4,5 bar); b-grupo $P$ (partículas de alumina com $145 \mu \mathrm{m}$ por $4 \mathrm{~s}$ a 4,5 bar); e c-grupo $S$ (partículas de alumina revestida por sílica com 30 um por $4 \mathrm{~s}$ a 4,5 bar).] 

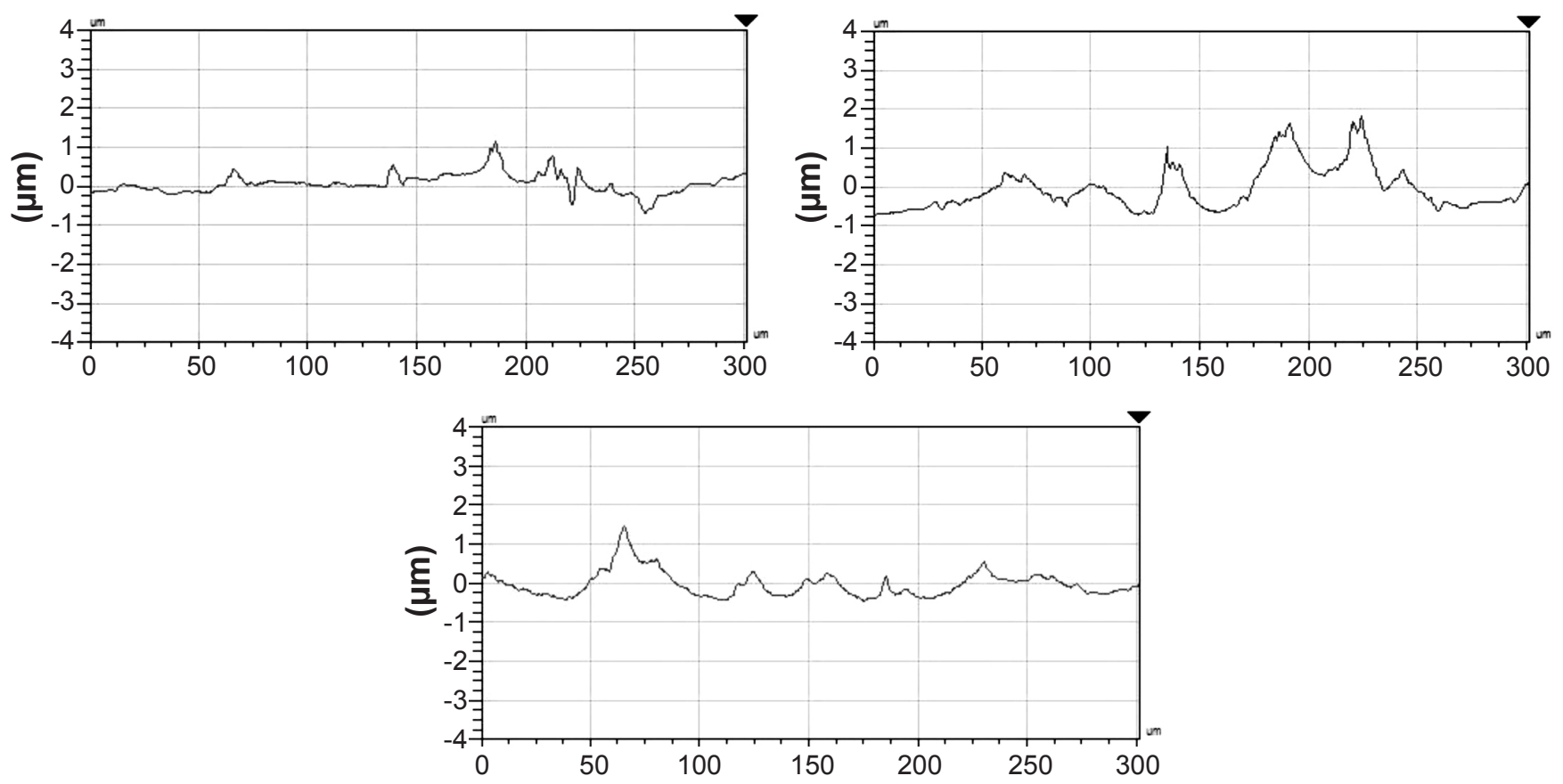

Figure 2: Roughness images and X profiles of the Y-TZP surface of: a- group M (alumina particle of $45 \mu \mathrm{m}$ for $4 \mathrm{~s}$ at $4.5 \mathrm{bar}$ ) following metal/zirconia primer application; b- group P (alumina particle of $145 \mu \mathrm{m}$ for $4 \mathrm{~s}$ at $4.5 \mathrm{bar}$ ) following metal/zirconia primer application; and c- group S (cojet particle of $30 \mu \mathrm{m}$ for $4 \mathrm{~s}$ at 4.5 bar) following silane coupling agent application.

[Figura 2: Imagens da rugosidade de superfície da cerâmica Y-TZP e gráfico do perfil no eixo $X$ de amostras do: a-grupo M (partículas de alumina com 45 um por $4 \mathrm{~s}$ a 4,5 bar) após a aplicação do metalzirconia primer; $b$ - grupo P (partículas de alumina com 145 um por $4 \mathrm{~s}$ a 4,5 bar) após a aplicação do metalzirconia primer; e c-grupo $S$ (partículas de alumina revestida por sílica com 30 m por 4 s a 4,5 bar) após a aplicação do agente de união silano.]

Table IV - Mean (SD) of roughness values in different parameters for Y-TZP surface treatments. *The same superscripted letters indicate no significant differences in the same column (Tukey's test, $\alpha=0.05$ ).

[Tabela IV - Média (DP) dos valores de rugosidade nos diferentes parâmetros para os diferentes tratamentos de superfície da Y-TZP. *Mesma letras sobrescritas indicam não haver diferença estatisticamente significante para mesma coluna (Teste de Tukey, $\alpha=0,05)$.]

\begin{tabular}{|c|c|c|c|c|c|c|c|}
\hline Groups & $\mathrm{Ra}(\mu \mathrm{m})$ & $\mathrm{Rq}(\mu \mathrm{m})$ & $\mathrm{Rz}(\mu \mathrm{m})$ & $\mathrm{X}$ - crossing & $\operatorname{Mr} 1(\%)$ & $\operatorname{Mr} 2(\%)$ & Sdr (\%) \\
\hline A & $0.11(0.01)^{\mathrm{i}}$ & $0.15(0.01)^{\mathrm{j}}$ & $1.57(0.1)^{\mathrm{j}}$ & $220(14)^{\mathrm{hi}}$ & $8.3(0.2)^{\mathrm{fg}}$ & $86.6(0.6)^{\mathrm{h}}$ & $1.6(0.1)^{\mathrm{k}}$ \\
\hline B & $0.24(0.01)^{\mathrm{h}}$ & $0.30(0.01)^{\mathrm{hi}}$ & $2.7(0.3)^{i}$ & $367(17)^{\mathrm{bcd}}$ & $10.5(0.3)^{\mathrm{bc}}$ & $90.9(0.4)^{\mathrm{ab}}$ & $13.8(0.9)^{\mathrm{j}}$ \\
\hline $\mathrm{C}$ & $0.28(0.01)^{\mathrm{gh}}$ & $0.35(0.02)^{\mathrm{hi}}$ & $3.8(0.3)^{\mathrm{fgh}}$ & $348(17)^{\mathrm{cd}}$ & $9.0(0.2)^{\operatorname{def}}$ & $88.9(0.7)^{\mathrm{ef}}$ & $17.1(1.1)^{\mathrm{h}}$ \\
\hline D & $0.46(0.02)^{\mathrm{cd}}$ & $0.56(0.02)^{\mathrm{de}}$ & $5.6(0.6)^{\mathrm{c}}$ & $266(40)^{\mathrm{f}}$ & $8.4(0.4)^{\mathrm{efg}}$ & $89.0(0.3)^{\mathrm{ef}}$ & $24.5(0.9)^{\mathrm{de}}$ \\
\hline E & - & - & - & - & - & - & - \\
\hline F & $0.44(0.02)^{\mathrm{cd}}$ & $0.58(0.03)^{\mathrm{e}}$ & $5.4(0.6)^{\mathrm{cd}}$ & $261(13)^{\mathrm{fg}}$ & $7.3(0.4)^{\mathrm{h}}$ & $85.1(0.3)^{\mathrm{i}}$ & $23.8(1.4)^{\mathrm{de}}$ \\
\hline $\mathrm{G}$ & $0.72(0.03)^{\mathrm{a}}$ & $0.92(0.06)^{b}$ & $6.9(0.6)^{\mathrm{ab}}$ & $186(9)^{\mathrm{i}}$ & $5.9(0.6)^{\mathrm{i}}$ & $87.6(0.6)^{\mathrm{gh}}$ & $28.0(1.3)^{\mathrm{ab}}$ \\
\hline $\mathrm{H}$ & $0.23(0.01)^{\mathrm{h}}$ & $0.29(0.01)^{\mathrm{i}}$ & $2.9(0.2)^{\mathrm{hi}}$ & $428(17)^{\mathrm{a}}$ & $11.5(0.9)^{\mathrm{a}}$ & $91.4(0.8)^{\mathrm{a}}$ & $16.1(0.9)^{\mathrm{hi}}$ \\
\hline I & $0.28(0.01)^{\mathrm{gh}}$ & $0.35(0.02)^{\mathrm{hi}}$ & $4.7(0.5)^{\operatorname{cdef}}$ & $379(22)^{\mathrm{bc}}$ & $9.3(0.3)^{\mathrm{d}}$ & $91.0(0.6)^{\mathrm{ab}}$ & $20.0(0.9)^{\mathrm{g}}$ \\
\hline $\mathrm{J}$ & $0.42(0.05)^{\mathrm{de}}$ & $0.53(0.06)^{\mathrm{ef}}$ & $5.3(0.4)^{\mathrm{cd}}$ & $311(7)^{\mathrm{e}}$ & $9.1(0.4)^{\mathrm{def}}$ & $89.7(0.6)^{\mathrm{de}}$ & $27.0(1.0)^{\mathrm{ab}}$ \\
\hline $\mathrm{K}$ & $0.21(0.01)^{\mathrm{h}}$ & $0.28(0.01)^{\mathrm{i}}$ & $3.6(0.4)^{\mathrm{ghi}}$ & $389(21)^{b}$ & $10.5(0.7)^{\mathrm{b}}$ & $89.8(0.3)^{\mathrm{cde}}$ & $15.2(0.5)^{\mathrm{ij}}$ \\
\hline $\mathrm{L}$ & $0.36(0.01)^{\mathrm{ef}}$ & $0.46(0.04)^{\mathrm{fg}}$ & $4.5(0.6)^{\operatorname{defg}}$ & $336(21)^{\mathrm{de}}$ & $8.9(0.2)^{\mathrm{def}}$ & $90.1(0.7)^{\mathrm{bcd}}$ & $23.1(0.6)^{\mathrm{ef}}$ \\
\hline M & $0.56(0.03)^{\mathrm{b}}$ & $0.75(0.05)^{\mathrm{c}}$ & $6.8(0.6)^{\mathrm{ab}}$ & $248(23)^{\mathrm{fgh}}$ & $9.6(0.5)^{\mathrm{cd}}$ & $90.8(0.6)^{\mathrm{abc}}$ & $26.3(1.2)^{\mathrm{bc}}$ \\
\hline $\mathrm{N}$ & - & - & - & - & - & - & - \\
\hline $\mathrm{O}$ & $0.53(0.05)^{\mathrm{b}}$ & $0.66(0.09)^{\mathrm{d}}$ & $6.6(0.6)^{b}$ & $226(16)^{\mathrm{gh}}$ & $7.0(0.8)^{\mathrm{h}}$ & $87.2(0.9)^{\mathrm{gh}}$ & $25.2(1.5)^{\mathrm{cd}}$ \\
\hline $\mathrm{P}$ & $0.75(0.09)^{\mathrm{a}}$ & $1.02(0.13)^{\mathrm{a}}$ & $7.7(1.3)^{\mathrm{a}}$ & $183(13)^{\mathrm{i}}$ & $7.6(0.5)^{\mathrm{gh}}$ & $88.0(0.8)^{\mathrm{fg}}$ & $28.8(1.0)^{\mathrm{a}}$ \\
\hline Q & $0.22(0.01)^{\mathrm{h}}$ & $0.28(0.01)^{\mathrm{i}}$ & $2.7(0.2)^{\mathrm{i}}$ & $436(36)^{a}$ & $11.0(0.4)^{\mathrm{ab}}$ & $91.0(0.6)^{\mathrm{ab}}$ & $16.3(0.7)^{\mathrm{hi}}$ \\
\hline $\mathrm{R}$ & $0.31(0.02)^{\mathrm{fg}}$ & $0.38(0.02)^{\mathrm{gh}}$ & $4.2(0.4)^{\mathrm{efg}}$ & $374(23)^{\mathrm{bc}}$ & $9.4(0.6)^{\mathrm{d}}$ & $90.4(0.3)^{\mathrm{abcd}}$ & $21.3(1.3)^{\mathrm{fg}}$ \\
\hline S & $0.49(0.05)^{\mathrm{bc}}$ & $0.61(0.07)^{\mathrm{de}}$ & $5.1(0.6)^{\mathrm{cde}}$ & $254(14)^{\mathrm{fgh}}$ & $9.2(0.5)^{\mathrm{de}}$ & $91.2(0.4)^{\mathrm{a}}$ & $26.4(0.9)^{\mathrm{bc}}$ \\
\hline
\end{tabular}




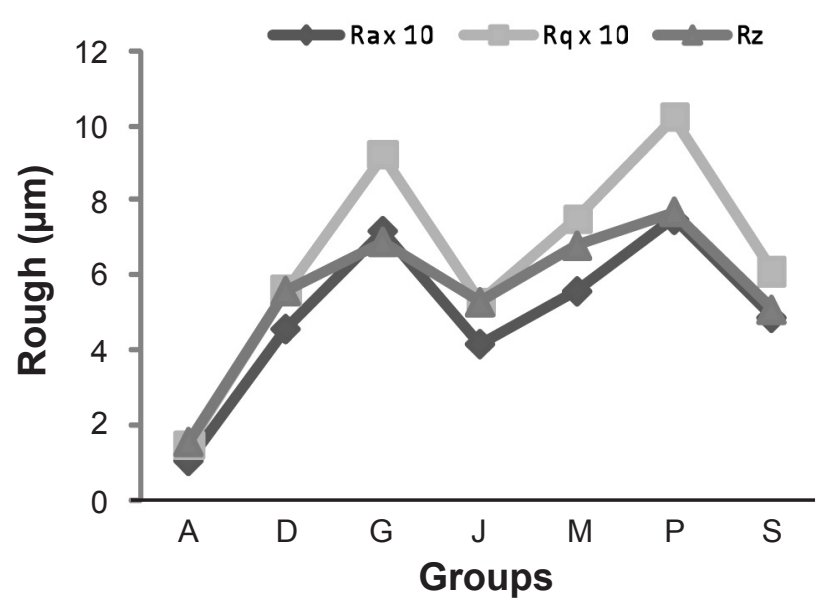

Figure 3: Graphic showing the roughness results according to the amplitude parameters $\mathrm{Ra}, \mathrm{Rq}$ and $\mathrm{Rz}$ for the groups at 4.5 bar compared to the control group A (polished surface): D) alumina particle of $45 \mu \mathrm{m}$ for $2 \mathrm{~s}$; G) alumina particle of $145 \mu \mathrm{m}$ for $2 \mathrm{~s}$; J) Cojet of $30 \mu \mathrm{m}$ for $2 \mathrm{~s}$; M) alumina particle of $45 \mu \mathrm{m}$ for $4 \mathrm{~s}$; P) alumina particle of $145 \mu \mathrm{m}$ for $4 \mathrm{~s}$; S) Cojet of $30 \mu \mathrm{m}$ for 4 $\mathrm{s}$. For the $\mathrm{Ra}$ and $\mathrm{Rq}$ graphs, the original roughness values were multiplied by 10 before inclusion in the graph.

[Figura 3: Gráfico mostrando os resultados de rugosidade para os parâmetros de amplitude $R a, R q$ e $R z$ para os grupos a 4,5 bar comparados ao grupo controle A (surperficie polida): D) partícula de alumina de $45 \mu \mathrm{m}$ por $2 \mathrm{~s} ; \mathrm{G}$ ) partícula de alumina de $145 \mu \mathrm{m}$ por $2 \mathrm{~s}$; J) Cojet de $30 \mu \mathrm{m}$ por $2 \mathrm{~s}$; M) partícula de alumina de 45 um por $2 \mathrm{~s}$; P) partícula de alumina de $145 \mu \mathrm{m}$ por 2 s; S) Cojet de 30 um por 2 s. Para as representações de Ra e Rq, os valores originais foram multiplicados por 10 antes de serem adicionados no gráfico.]

\section{DISCUSSION}

SEM and AFM analysis have been used to evaluate surface roughness in the dentistry literature $[19,21,22$, $34,35,43]$. This study used an interference microscopic (IM), which is an optical technique used to measure surface roughness by the optical interference technique, where the light intensity of the fringes is related to the surface height. It possesses a nanometric vertical resolution with a dynamic range (scan size) that greatly exceeds that of probe microscopes providing fast images of the surface (such as SEM), with a roughness parameter supported by 3D image (such as AFM). These IM advantages justified the choice and qualitative and quantitative analysis of roughness following the alumina particle (sandblasted, SB) and silica modified alumina particle (silica coating systems, SC) protocol applications.

It is known that resin cements adhere poorly on Y-TZP, however topographic alteration of a surface substantially affects the macroscopic behavior of a material [44, 45]. Physical and chemical surface modifications can alter certain properties, such as surface energy and wettability, increasing bond strength and the long-term survival of interface adhesion $[44,45]$. In Y-TZP surface treatment for a clinical purpose, SC and SB protocols have been applied easily at chairside and have a good price-performance ratio; however, they can cause subsurface damage [46, 47] and some tetragonal to monoclinic phase transformation can occur when alumina particle is used [33, 48]. Based on their initial results, Cattani Lorente et al reported that the impact-induced surface flaws caused by Cojet particles had no effect on strength, observing that mean survival load at failure following cyclic fatigue was similar before and after blasting [49].

Studies concerning interface adhesion at the metal/ zirconia interface have suggested that a stable monoclinic phase decreased bond strength results [50], nevertheless it has been reported that surface activation and the cleaning effect of air-particle abrasion associated with bond agents are necessary for hydrolysis resistant chemical bonding to Y-TZP [19, 21, 22, 34, 42]. Analysis of the current results revealed that the roughness patterns were altered when using different surface treatment protocols, thus the hypothesis was accepted.

Knowledge of surface texture is important to adhesion studies. The use of particle abrasion treatment on Y-TZP generates pit-like surface features with high aspect ratios and different degrees of symmetry of surface morphologies (heights about the mean plane). Frequently, Ra has been used to express changes in zirconia surface in the dentistry literature $[28,30,34]$; however, the mean roughness $(\mathrm{Ra})$ associated with $2 \mathrm{D}$ surface images only provides limited information and can lead to an erroneous interpretation of surface roughness. Ra cannot detect differences in the spacing of surface irregularities (peaks and valleys), thus it cannot providing information regarding their shape. Moreover, limited scan size could underestimate values, leading to unrepresentative results, principally after surface treatment using larger particles. Still, Rz presented advantages over a single peak-to-valley height (Rt), by reducing the effects of odd scratches or non-typical irregularities. Ra and Rz parameters showed similar results, a uniform standard of roughness was presented on the surface, because the height of peaks and valleys did not vary. However, in the present study, a large difference in these parameters indicated the presence of a spot defect on the surface. A larger scan size provided clearer support for this finding. Defects and roughness can appear on the surface following the SC and SB protocols [33] due to sputtering of grains of zirconia, intergrain microcracks or by phase transformation, produced by the higher impact energy of particles, creating a new surface with new physical and chemical properties. Moreover, the use of correct roughness parameters and a large scan size to evaluate the effect of topographic modification can help in understanding the behavior of the new surface in relation to bond strength [51].

Analysis of the results of this study showed that $\mathrm{Ra}, \mathrm{Rq}$ and $\mathrm{Rz}$ increased with pressure and particle size (Table IV and Fig. 3). However, the large difference between Ra and $\mathrm{Rz}$ revealed the presence of deep valleys in the surface for all groups. When the $145 \mu \mathrm{m}$ alumina particles were used, $\mathrm{Rz}$ achieved the highest value, suggesting that big particles 
promoted more punctual damage in a surface than small particles, regardless of the pressure (Figs. 1 and 3).

In order to obtain information on the shape and size of peaks and valleys, parameters from the functional volume family associated with X-crossing parameter were analyzed. Mr1, Mr2 and X-crossing facilitated a clearer understanding of surface texture following the different airbone abrasion protocols. For example, surface SB for $2 \mathrm{~s}$ using $145 \mu \mathrm{m}$ alumina particles at 2.5 bar (group F) and SC for $4 \mathrm{~s}$ at 4.5 bar (group $\mathrm{S}$ ) did not produce any statistical differences in $\mathrm{Ra}, \mathrm{Rq}$ or $\mathrm{Rz}$ parameters in relation to surface roughness. Using only these parameters could lead to the assumption that the behavior of these surfaces was the same; however, this would not be accurate if the Sdr parameter were evaluated. The surface area was larger than SB (first protocol example) when SC (second protocol example) was used. X-crossing suggested that the SC protocol produced more peaks and valleys than the SB protocol, which was confirmed by the regular value obtained for $\mathrm{Mr} 1$ and $\mathrm{Mr} 2$ under SC against greater valley volume $(\mathrm{Mr} 2)$ under $\mathrm{SB}$ and in the X profile (Fig. 1).

In general, $\mathrm{X}$-crossing and $\mathrm{Mr} 1$ showed no statistical significance for the same particle $(45 \mu \mathrm{m}$ and $145 \mu \mathrm{m}$ alumina particles and Cojet) and pressure $(1.5,2.5,4.5)$ for the different protocol durations ( 2 and 4 ), showing that despite the results of $\mathrm{Ra}, \mathrm{Rq}$ and $\mathrm{Rz}$ at different pressure and durations, the pattern of roughness seems to be the same, while only the amplitude of these bidimensional parameters varied. $\mathrm{X}$-crossing presented an inverse correlation with $\mathrm{Ra}, \mathrm{Rq}, \mathrm{Rz}$ and Sdr parameters. Larger particle size $(145 \mu \mathrm{m})$, pressure (4.5 bar) and duration (4 s) increased the values for $\mathrm{Ra}, \mathrm{Rq}, \mathrm{Rz}$ and $\mathrm{Sdr}$, while the $\mathrm{X}$-crossing values decreased. These results, in association with the X-profile and 3D images (Fig. 1), suggested that increasing the pressure, particle size, and duration promoted larger and deeper valleys. This approach assumes that the bond agent infiltration in the grooves and valleys is facilitated when using high pressure, big particle size or longer duration of SC or SB protocols. These protocols caused massive sputtering on the Y-TZP surface [33, 46], thus air-abrasion with small-sized particles should be considered due to the potential reduction in flexural strength and possible material loss with bigger particles, particularly along the margins of restorations [6]. Kern et al showed that the association of bonding agent and airborne particle abrasion protocol was more critical when using lower pressure to promote surface roughness [8], probably because the valleys created during SB and SC were very thin, which made resin cement flow more difficult, filling the surface roughness. When $45 \mu \mathrm{m}$ alumina particle and $30 \mu \mathrm{m}$ alumina coated silica particle were used for $2 \mathrm{~s}$, $\mathrm{SC}$ groups presented greater proportionality in increasing the surface area (Sdr) than the SB groups. However, for 4 $\mathrm{s}$ showed no statistical significance. Probably, the initial difference ( $2 \mathrm{~s}$ ) was caused by additional silica coating on the surface presented in the SC groups. Further roughness parameters, as Rc (mean height of the profile elements
- peak and valley) and RSm (mean width of the profile elements - peak and valley), could be evaluated in order to understand better the effect of duration and particle on the profile elements.

Previous studies that used high pressure (4-7 bar) with $110 \mu \mathrm{m}$ alumina particles and $30 \mu \mathrm{m}$ alumina-coated silica particles (Cojet) showed no influence of surface roughness on the bond strength results of resin cement and zirconia ceramic (Procera) [30]. Using Procera zirconia ceramic and different resin cements (Panavia, Relyx Arc and Relyx Unicem) with the same pressure (2.5 bar) and 50 and 100 $\mu \mathrm{m}$ alumina particles, Phark showed that particle size did not present a significant effect on the bond strength [52]. In another study, Ozcan used Lava zirconia ceramic and Panavia $\mathrm{F}$ with 50 and $100 \mu \mathrm{m}$ alumina particles at 2.8 bar and observed no significant differences between groups regarding bond strength [6].

Previous studies showed that the resin cement/ceramics interface, analyzed by SEM images, resulted in a relatively irregular interface, independent of the sandblasted ceramic protocol [34], suggesting that resin cement was not sufficiently flowable to maintain perfect contact with the surface submitted to air-abrasion. Thus, different resin cement viscosities influence the bond strength results [51]. Fig. 2 suggests that the bond agent (primer or silane) partially fills the grooves, reducing surface roughness. This is in agreement with previous studies that showed no stability in resin cement bond strength used on Y-TZP surfaces that were submitted to airborne particle abrasion [22]. Thus, it is very important to use a bonding agent compatible with the ceramic and the resin cement following the increase in surface roughness to stabilize interfacial bonding [35, 42]. This should reduce the presence of defects in interface adhesion that could promote local stress, resulting in a reduction in bond strength. Hence, the bonding agent assumes an important part of the bond strength, not only due to chemical [29], but also due to physical microretention, suggesting that chemical compatibility between the bonding agent and resin cement [19], the hydrophobic properties and the ability of interphase Y-TZP/bonding agent that support the contraction of the resin cement are more important than the physical properties of the resin cement at resisting hydrolysis and creating a stable long-term bond strength.

Different mechanisms of micro mechanical retention could be involved in bond strength when surface roughness is increased. Aside from cleaning the surface or any hooking or holding effects, roughness increases the surface area across which intermolecular forces act and may induce microstructural changes in the cured adhesive (possibly increased crystallinity), both of which could act to increase bond strength and increase energy dissipation in the adhesive during joint failure [53].

Further studies are required to evaluate the possible effects of SB and SC protocols on roughness patterns for different Y-TZP brands to determine the optimal conditions of airborne particle abrasion on bond strength with minimal damage to the ceramic surface. 


\section{CONCLUSION}

The sandblasting protocols using alumina particles and silica modified alumina particles performed in this study, allow us to affirm that: a) application duration, particle size and pressure influenced the topographic pattern and amplitude of the roughness parameters analyzed by ANOVA and Tukey tests; b) the association of amplitude and functional parameters provide details regarding the differences in topographic patterns to similar surface roughness.

\section{REFERENCES}

[1] P. Derand, T. Derand, Int. J. Prosthodont. 13, 2 (2000) 131.

[2] S. M. Wegner, M. Kern, J. Adhes. Dent. 2, 2 (2000) 139.

[3] J. P. Matinlinna, T. Heikkinen, M. Özcan, L. V. Lassila, P. K. Vallittu, Dent. Mater. 22, 9 (2006) 824.

[4] M. N. Aboushelib, C. J. Kleverlaan, A. J. Feilzer, J. Prosthet. Dent. 98, 5 (2007) 379.

[5] A. Della Bona, T. A. Donassollo, F. F. Demarco, A. A. Barrett, J. J. Mecholsky Jr, Dent. Mater. 23, 6 (2007) 769.

[6] M. Özcan, H. Nijhuis, L. F. Valandro, Dent. Mater. J. 27, $1(2008) 99$.

[7] M. N. Aboushelib, H. Mirmohamadi, J. P. Matinlinna, E. Kukk, H. F. Ounsi, Z. Salameh, Dent. Mater. 25, 8 (2009) 989.

[8] M. Kern, A. Barloi, B. Yang, J. Dent. Res. 88, 9 (2009) 817.

[9] D. M. Qeblawi, C. A. Munoz, J. D Brewer, E. A. Monaco Jr, J. Prosthet. Dent. 4 (2010) 210.

[10] J. R. Piascik, E. J. Swift, J. Y. Thompson, S. Grego, B. R. Stoner, Dent. Mater. 25, 9 (2009) 1116.

[11] C. Y. K. Lung, E. Kukk, T. Hägerth, J. P. Matinlinna, Appl. Surf. Sci. (2010) ; doi:10.1016/j.apsusc.2010.08.029.

[12] M. Wolfart, F. Lehmann, S. Wolfart, M. Kern, Dent. Mater. 23, 1 (2007) 45.

[13] M. B. Blatz, J. H. Phark, F. Ozer, F. K. Mante, N. Saleh, M. Bergler, A. Sadan, Clin. Oral. Investig. 14, 2 (2010) 187. [14] S. Kitayama, T. Nikaido, R. Takahashi, L. Zhu, M. Ikeda, R. M. Foxton, A. Sadr, J. Tagami, Dent. Mater. 26, 5 (2010) 426.

[15] T. Derand, M. Molin, K. Kvam, Dent. Mater. 21, 12 (2005) 1158.

[16] U. Lohbauer, F. A. Muller, A. Petschelt, Dent. Mater. 24, 2 (2008) 250.

[17] A. N. Cavalcanti, R. M. Foxton, T. F. Watson, M. T. Oliveira, M. Giannini, G. M. Marchi, Oper. Dent. 34, 3 (2009) 280.

[18] M. Behr, P. Proff, C. Kolbeck, S. Langrieger, J. Kunze, G. Handel, M. Rosentritt, J. Mech. Behav. Biomed. Mater. 4, 1 (2010) 2.

[19] P. Magne, M. P, Paranhos, L. H. Burnett Jr., Dent. Mater. 26, 4 (2010) 345.

[20] H. Mirmohammadi, M. N. Aboushelib, Z. Salameh, A. J. Feilzer, C. J. Kleverlaan, Dent. Mater. 26, 8 (2010) 786.
[21] K. Takeuchi, A. Fujishima, A. Manabe, S. Kuriyama, Y. Hotta, Y. Tamaki, T. Miyazak, Dent. Mater. J. 29, 3 (2010) 316.

[22] B. Yang, A. Barloi, M. Kern, Dent. Mater. 26, 1 (2010) 44.

[23] S. S. Atsu, M. A. Kilicarslan, H. C. Kucukesmen, P. S. Aka, J. Prosthet. Dent. 95, 6 (2006) 430.

[24] O. Kumbuloglu, L. V. Lassila, A. User, P. K. Vallittu, Oper. Dent. 31, 2 (2006) 248.

[25] M. B. Blatz, G. Chiche, S. Holst, A. Sadan, Quintessence Int. 38, 9 (2007) 745.

[26] T. T. Heikkinen, L. V. Lassila, J. P. Matinlinna, P. K. Vallittu, Acta Odontol. Scand. 65, 4 (2007) 241.

[27] M. Özcan, S. Kerkdijk, L. F. Valandro, Clin. Oral Investig. 12, 3 (2008) 279.

[28] R. Tanaka, A. Fujishima, Y. Shibata, A. Manabe, T. Miyazaki, J. Dent. Res. 87, 7 (2008) 666.

[29] M. Tsukakoshi, A. Shinya, H. Gomi, L. V. Lassila, P. K. Vallittu, Dent. Mater. J. 27, 2 (2008) 159.

[30] R. C. de Oyague, F. Monticelli, M. Toledano, E. Osorio, M. Ferrari, R. Osorio, Dent. Mater. 25, 2 (2009) 172.

[31] F. P. Nothdurft, P. J. Motter, P. R. Pospiech, Clin. Oral Investig. 13, 2 (2009) 229.

[32] J. H. Phark, S. Duarte Jr, A. Hernandez, M. B. Blatz, A. Sadan, Acta Odontol. Scand. 67 (2009) 346.

[33] M. C. Lorente, S. S. Scherrer, J. Richard, R. Demellayer, M. Amez-Droz, H. W. Wiskott, Dent. Mater. 26, 11 (2010) 1035.

[34] A. Casucci, C. Mazzitelli, F. Monticelli, Manuel Toledanoc, R. Osorio, E. Osorio, F. Papacchini, M. Ferrari, Dent. Mater. 26, 8 (2010) 751.

[35] J. Y. Yun, S. R. Ha, J. B. Lee, S. H. Kim, Dent. Mater. 26, 7 (2010) 650.

[36] P. F. Manicone, P. Rossi Iommetti, L. Raffaelli, J. Dent. 35, 11 (2007) 819.

[37] B. Yang, S. Wolfart, M. Scharnberg, K. Ludwig, R. Adelung, M. Kern, J. Dent. Res. 86, 8 (2007) 749.

[38] G. Akgungor, D. Sen, M. Aydin, J. Prosthet. Dent. 995 (2008) 388 .

[39] I. Denry, J. R. Kelly, Dent. Mater. 24, 3 (2008) 299.

[40] J. Lindgren, J. Smeds, G. Sjogren, Oper. Dent. 33, 6 (2008) 675.

[41] A. Casucci, E. Osorio, R. Osorio, F. Monticelli, M. Toledano, C. Mazzitelli, M. Ferrari, J. Dent. 37, 11 (2009) 891.

[42] F. Lehmann, M. Kern M, J. Adhes. Dent. 116 (2009) 479.

[43] R. Shahin, M. Kern, Dent. Mater. 26, 9 (2010) 922.

[44] D. Myers, Surfaces, Interfaces, and Colloids: Principles and Application, New York (1999).

[45] D. E. Packham, Adhesion science and engineering 2: surfaces, chemistry and applications. Surface roughness and adhesion, Elsevier, Amsterdam (2002).

[46] T. Kosmac, C. Oblak, P. Jevnikar, N. Funduk, L. Marion, Dent. Mater. 15 (1999) 426.

[47] Y. Zhang, B. R. Lawn, E. D. Rekow, V. P. Thompson, J. Biomed. Mater. Res. Appl. Biomater. 71 (2004) 381. 
[48] S. Karakoca, H. Yilmaz, J. Biomed. Mater. Res. B Appl. Biomater. 91, 2 (2009) 930.

[49] M. Cattani Lorente, S. S. Scherrer, J. Richard, R. Demellayer, M. Amez-Droz, H. W. A. Wiskott, Dent. Mater. 26, 11 (2010) 1035.

[50] M. C. Muñoz, S. Gallego, J. I. Beltrán, J. Cerdá, Surf. Sci. Rep. 61 (2006) 303.
[51] D. E. Packham, Int. J. Adhes. Adhes. 23 (2003) 437.

[52] J. H. Phark, S. Duarte Jr, M. Blatz, A. Sadanm, J. Prosthet. Dent. 101, 1 (2009) 29.

[53] J. C. Berg, Adhesion science and engineering 2: surfaces, chemistry and applications, Semi-empirical strategies for predicting adhesion, Elsevier, Amsterdam (2002)

(Rec. 13/03/2011, Rev. 07/09/2011, Ac. 11/01/2012) 